\title{
PILOT STUDY OF CONTACT SENSITIZATION OF FORMALDEHYDE-RELEASERS, FORMALDEHYDE AND GLUTARALDEHYDE IN DENTAL STUDENTS
}

\author{
Lyapina Maya, ${ }^{1}$ Dencheva Maria, ${ }^{2}$ Krasteva Assya, ${ }^{2}$ Tzekova Mariana, ${ }^{2}$ \\ Deliverska Mariela, ${ }^{3}$ Kisselova Angelina ${ }^{2}$ \\ ${ }^{1}$ Department "Hygiene, Medical Ecology and Nutrition", Medical University - Sofia, \\ Medical Faculty, Sofia, Bulgaria \\ ${ }^{2}$ Department "Oral and Image Diagnostic", Medical University - Sofia, Faculty of Dental Medicine, Sofia, Bulgaria \\ ${ }^{3}$ Department "Medical Ethics and Law", Medical University - Sofia, Faculty of Public Health, Sofia, Bulgaria \\ Primljen/Received 18. 01. 2016. god. \\ Prihvaćen/Accepted 01. 03. 2016. god.
}

Abstract: Introduction: Occupational allergic contact sensitization is common in dental personnel. Some of the most common occupational allergens in dental practice are some formaldehyde-releasers, formaldehyde and glutaraldehyde.

Aim: The aim of the present study was to evaluate the rate of contact sensitization to formaldehyde, quaternium-15, imidazolidinyl urea, diazolidinyl urea, and to glutaraldehyde in students of dental medicine and dental patients.

Material and methods: A total of 50 participants were included in the study: 40 students of dental medicine exposed to formaldehyde-releasers, formaldehyde and glutaraldehyde during the course of their education; 10 dental patients without occupational exposure to the latter substances served as a control group. All of them were patch-tested with the studied allergens.

Results: The sensitization rate to formaldehyde was significantly higher in the group of dental patients if compared to the one of dental students $\chi^{2}=5.37 ; p=$ 0.021). Positive skin patch test reactions to quaternium-15 and to imidazolidinyl urea were observed only in the group of dental students. A significantly higher rate of sensitization to diazolidinyl urea, if compared to the one to imidazolidinyl urea $\left(\chi^{2}=5.4 ; \mathrm{p}=0.02\right)$ and to quaternium-15 $\left(\chi^{2}=6.76 ; \mathrm{p}=0.009\right)$, as well as to glutaraldehyde, if compared to the one to quaternium-15 $\left(\chi^{2}\right.$ $=3.96 ; \mathrm{p}=0.04)$ for the whole studied population was established. For the whole studied population, significantly increased rate of concomitant sensitization to formaldehyde and glutaraldehyde $\left(\chi^{2}=6.18 p=0.013\right)$, as well as to diazolidinyl urea and to glutaraldehyde was established $\left(\chi^{2}=9.12 \mathrm{p}=0.003\right)$.

Conclusions: We consider the importance of exposure to diazolidinyl urea, quaternium-15, imidazolidinyl urea and glutaraldehyde during the course of practical education in dentistry for the onset of sensitization. The exposure to formaldehyde is ubiquitous and is difficult to distinguish the roles of environmental and occupational exposures. The promotion of proper personal protection as well as adequate information on occupational chemical hazards should start as early as during the first years of education in dentistry.

Key words: contact sensitization, students of dental medicine, formaldehyde, formaldehyde-releasing preservatives, glutaraldehyde.

\section{INTRODUCTION}

Occupational allergic contact sensitization is common in dental personnel, since in their daily activities they are exposed to the numerous chemical agents. Some of the most common healthcare allergens present biocides, commonly applied for sterilization of medical devices that are sensitive to normal heat or steam sterilization processes (glutaraldehyde) and disinfection of surfaces (quaternary ammonia compounds). Increased rates of sensitization to the majority of the above-mentioned allergens among dental specialists are reported (1). Preservatives are biocidal chemicals added to cosmetics, topical medicaments, consumer goods, foods, and industrial products to protect them against microbial spoilage and to protect the consumer 
against infection (2). They prevent growth of bacteria, molds, yeast, and algae in body, skin, and hair care products, personal care products, domestic preparations, and industrial products $(3,4)$. Preservatives were identified as the most common cosmetic contact allergens in several recent studies $(5,6)$, but they are applied in various materials used in everyday dental practice as well. They can be classified into three broad categories: antimicrobials, antioxidants, and ultraviolet light absorbers. The antimicrobial agents can be further divided into formaldehyde preservatives, formaldehyde-releasers, and non-formaldehyde-releasing preservatives.

Formaldehyde is an inexpensive biocidal preservative used in a wide range of products, such as tissue specimen and cadaveric preservation solutions, nail polish, wrinkle-free fabrics, etc. In dentistry it is used as an ingredient of root canal filling materials, or could leach from dental composites. In the reported North American Contact Dermatitis Group (NACDG) frequency data, formaldehyde ranked seventh, with $5.8 \%$ positive reactions noted in the 4,308 patients referred for testing (7). This high rank as well as formaldehyde's ubiquity and important role as a top allergen have been noted for the last 75 years (8). Its historical importance stems from its effectiveness in preventing contamination of personal hygiene products (9). Notably, it is also 1 of only 5 chemicals that have been listed by the Consumer Product Safety Commission as "strong sensitizers" since 1961 (10). Formaldehyde is the American Contact Dermatitis Society Contact Allergen of the Year for 2015. The exposure is widespread, and contact allergy might be difficult to suspect in the individual dermatitis patient (11).

Formaldehyde-releasing preservatives (FRP) were developed to avoid formaldehyde-induced contact allergies assuming that the formaldehyde release level would not be sufficient from the releaser to cause a skin reaction (12). However, many of them have also been demonstrated to be contact allergens, some related to the release of formaldehyde, while others by their own chemical properties (13). Formaldehyde-releasing preservatives include quaternium-15, diazolidinyl urea, imidazolidinyl urea, 2-bromo-2-nitropropane-1.3-diol, and 1,3-Dimethylol-5,5-dimethylhydantoin DMDM hydantoin (14). They are among the leading contact allergens and are found in many medications, household cleansers, and personal health products (9). It is important for people to be aware of sources of formaldehyde exposure and understand that many products containing formaldehyde or FRPs may not indicate this on their labels. A study by Rastogi reported that 33\% of 67 moisturizers evaluated did not have proper labeling in regards to their formaldehyde/FRP content (15).
For over 40 years, glutaraldehyde was the primary choice for disinfecting heat-sensitive medical devices, such as dental equipment and endoscopic instruments, and its toxicity has been well described, and its use has been associated with dermatitis and occupational asthma. Increased rates of sensitization to the majority of the above-mentioned allergens among dental specialists are reported (1). Quite a few data in the available literature was found concerning the rate of contact sensitization to these substances among dental students.

\section{AIM}

The aim of the present study was to evaluate the rate of contact sensitization to formaldehyde, some formaldehyde-releasing preservatives and to glutaraldehyde in students of dental medicine and dental patients.

\section{MATERIAL AND METHODS}

\section{Subjects}

A total of 50 participants were included in the study: 40 students of dental medicine from the Faculty of Dental Medicine, Medical University - Sofia (19 male and 21 female, mean age $25.30 \pm 9.1$ ), exposed to formaldehyde, some formaldehyde-releasing preservatives and to glutaraldehyde during the course of their practical education (Group E); 10 randomly selected dental patients (4 male and 6 female, mean age $47.70 \pm$ 17.6), without occupational exposure to the investigated substances served as a control group (Group C). The mean age of the individuals from Group $\mathrm{C}$ was significantly higher if compared with Group $\mathrm{E}(\mathrm{t}=-5.6, \mathrm{p}$ $<0.005)$. General characteristics of the studied subjects are presented in Table 1. The study was approved by the Medical Ethics Board at Medical University Sofia. All the participants were informed about the purpose of the study and gave their written informed consent.

\section{Methods}

Skin patch testing with formaldehyde (2.0\%/aq), quaternium-15 (1.0\%/pet), imidazolidinyl urea (2.0\%/pet), diazolidinyl urea $(2.0 \% /$ pet $)$, and glutaraldehyde $(0.2 \% /$ pet, Chemotechnique Diagnostics) was performed according to the Jadassohn \& Bloch classical methods for diagnosis of contact allergy, by placing the allergens in IQ-Ultra hypoallergenic patches of Chemotechnique Diagnostics (IQ Chambers ${ }^{\circledR}$, Vellinge, Sweden). Lack of anti-allergic medication constituted a mandatory condition before placing the patches and during the testing. Patches with allergens were applied on the back of the tested individuals, reading of the test was perfor- 
med on day 2, several hours after removing the patches, with control revision on day 3. Interpretation of reaction sites was based on the method recommended by the International Contact Dermatitis Research Group (ICDRG). Interpretation key based on recommendations by the ICDRG was applied.

Statistical analysis. The statistics were calculated with SPSS 19.0. The following statistics available for cross-tabulation were used: multiple correspondent analysis, Chi -square test, Fisher Exact Test for statistical significance. Values of $p<0.05$ were accepted as statistically significant.

\section{RESULTS}

Data concerning the frequency of positive patch test reactions to the studied preservatives in the investigated groups are summarized in Table 2.

As shown in Table 2, the highest was the frequency of positive skin patch test among dental students to glutaraldehyde, and the lowest - to quaternium-15; among the whole studied by us population of 50 individuals, the established frequency of sensitization was highest to diazolidinyl urea, lowest - again to quaternium-15. The sensitization rate to formaldehyde was significantly higher in the group of dental patients if compared with the one of dental students $\left(\chi^{2}=5.37 ; p=\right.$ $0.021)$. No statistically significant differences between Group E and Group C regarding the rates of sensitization to the other studied allergens were revealed $(\mathrm{p}>$ $0.05)$. Furthermore, for the whole studied population, a significantly higher rate of sensitization to diazolidinyl urea, if compared to the one to imidazolidinyl urea $\left(\chi^{2}\right.$ $=5.4 ; \mathrm{p}=0.02)$ and to quaternium-15 $\left(\chi^{2}=6.76 ; \mathrm{p}=\right.$ $0.009)$, as well as to glutaraldehyde, if compared to the one to quaternium-15 $\left(\chi^{2}=3.96 ; \mathrm{p}=0.04\right)$ was established. The statistical analysis of the results didn't reveal other significant differences in sensitization rates.

The distribution of concomitant/cross sensitization to the included in the study preservatives in the group of dental students and the in whole population is presented in Table 3 and Table 4. Significantly higher rate of concomitant sensitization to diazolidinyl urea and to glutaraldehyde was established $\left(\chi^{2}=9.12 \mathrm{p}=\right.$ 0.003). Furthermore, significantly increased rate of concomitant sensitization to formaldehyde and glutaraldehyde was revealed $\left(\chi^{2}=6.18 p=0.013\right)$. The rate of concomitant sensitization to formaldehyde and to glutaraldehyde for the group of dental students was $(15.0 \%)$. No statistically significant differences regarding the sensitization rates and the type of exposure, age and gender characteristics of the studied population were revealed.

\section{DISCUSSION}

Aldehydes, e.g. formaldehyde, FLP preservatives and glutaraldehyde represent an important class of disinfectants, broadly used throughout the world for various purposes. They are well known for their irritant and/or allergenic properties, and are of daily concern in

Table 1. General characteristics of the studied groups

\begin{tabular}{|l|c|c|c|c|}
\hline \multirow{2}{*}{\multicolumn{1}{|c|}{ Group }} & \multicolumn{4}{c|}{ Respondents } \\
\cline { 2 - 5 } & $\begin{array}{c}\text { age (years) } \\
\text { (M } \pm \text { SD) }\end{array}$ & $\begin{array}{c}\text { male } \\
{[\mathbf{n}(\%)]}\end{array}$ & $\begin{array}{c}\text { female } \\
{[\mathbf{( \% )}(\%)]}\end{array}$ & $\begin{array}{c}\text { total } \\
{[\mathbf{n}(\%)]}\end{array}$ \\
\hline Students of dental medicine & $25.30 \pm 9.1$ & $19(47.5)$ & $21(52.5)$ & $40(80.0)$ \\
\hline Patients without occupational exposure & $47.70 \pm 17.6$ & $4(40.0)$ & $6(60.0)$ & $10(20.0)$ \\
\hline
\end{tabular}

Table 2. Distribution of positive skin patch test reactions to the studied allergens among the studied groups

\begin{tabular}{|l|c|c|c|}
\hline STUDIED ALLERGEN & $\begin{array}{c}\text { Positive reactions } \\
\text { in dental students } \\
\text { N (\%) }\end{array}$ & $\begin{array}{c}\text { Positive reactions } \\
\text { in control group of } \\
\text { dental patients } \\
\mathbf{N}(\%)\end{array}$ & $\begin{array}{c}\text { Positive reactions } \\
\text { Total } \\
\text { N (\%) }\end{array}$ \\
\hline Formaldehyde & $9(22.5)$ & $\begin{array}{c}6(60.0) \\
\chi^{2}=5.37 ; \mathrm{p}=0.021\end{array}$ & $15(30.0)$ \\
\hline Quaternium-15 & $6(15.0)$ & - & $\mathbf{6}(12.0)$ \\
\hline Imidazolidinyl urea & $7(17.5)$ & - & $7(14.0)$ \\
\hline Diazolidinyl urea & $12(30.0)$ & $5(50.0)$ & $* * \nabla_{17}(34.0) * \nabla *$ \\
\hline Glutaraldehyde & $13(32.5)$ & $1(10)$ & $14(28.0)$ \\
\hline
\end{tabular}

${ }^{*} \chi^{2}=5.4, \mathrm{p}=0.02 ;{ }^{* *} \chi^{2}=3.96, \mathrm{p}=0.04 ;{ }^{* * *} \chi^{2}=6.76, \mathrm{p}=0.009$ 
Table 3. Distribution of the concomitant/cross sensitization between the studied preservatives in the group of dental students $(n=40)$

\begin{tabular}{|c|l|c|c|c|c|c|}
\hline $\mathrm{N}^{\circ}$ & \multicolumn{1}{|c|}{ ALLERGEN } & 1 & 2 & 3 & 4 & 5 \\
\hline 1 & Imidazolidinyl urea & 7 & 1 & 2 & 3 & 2 \\
\hline 2 & Quaternium-15 & 1 & 6 & 2 & 3 & 3 \\
\hline 3 & Diazolidinyl urea & 2 & 2 & 12 & 8 & 5 \\
\hline 4 & Glutaraldehyde & 3 & 3 & 8 & 13 & 6 \\
\hline 5 & Formaldehyde & 2 & 3 & 5 & 6 & 9 \\
\hline
\end{tabular}

* The numbers on the first row of the table indicate the corresponding allergen from column 2

Table 4. Distribution of the concomitant/cross sensitization between the studied preservatives in the whole population $(n=50)$

\begin{tabular}{|c|l|c|c|c|c|c|}
\hline $\mathrm{N}^{\circ}$ & \multicolumn{1}{|c|}{ ALLERGEN } & 1 & 2 & 3 & 4 & 5 \\
\hline 1 & Imidazolidinyl urea & 7 & 1 & 2 & 3 & 2 \\
\hline 2 & Quaternium-15 & 1 & 6 & 2 & 3 & 3 \\
\hline 3 & Diazolidinyl urea & 2 & 2 & 17 & $8^{* * *}$ & 10 \\
\hline 4 & Glutaraldehyde & 3 & 3 & 8 & 14 & $6^{* *}$ \\
\hline 5 & Formaldehyde & 2 & 3 & 10 & 6 & 15 \\
\hline
\end{tabular}

* The numbers on the first row of the table indicate the corresponding allergen from column 2

** Significantly increased rate of concomitant sensitization to formaldehyde and glutaraldehyde $\left(\chi^{2}=6.18 \mathrm{p}=0.013\right)$

${ }^{* * *}$ Significantly increased rate of concomitant sensitization to diazolidinyl urea and to glutaraldehyde $\left(\chi^{2}=9.12\right.$ $\mathrm{p}=0.003)$

occupational and/or environmental dermatology. Formaldehyde is the undisputed "leader" of aldehydes. Its use is so ubiquitous that it has always been present in the baseline series of patch tests (16). Occupational formaldehyde allergy is common in workers using protective creams, detergents, and liquid soaps. According to the FDA Voluntary Cosmetic Registration Program database, about $20 \%$ of personal health products and cosmetics contain a FRP, with imidazolidinyl urea as the most common (17). According to Latorre (2011) the most frequent allergens are formaldehyde $(1.72 \%)$, imidazolidinyl urea $(1.05 \%)$, quaternium-15 $(0.88 \%)$, and diazolidinyl urea (0.79\%) (18). Kadivar et al. (2015) reported significantly more work-related allergic contact dermatitis, especially to formaldehyde, quaternium-15, and glutaraldehyde among health care workers (19). Almost $80 \%$ of patients were exposed to quaternium- 15 through a moisturizer; hair care products and makeup were also common sources (13). According to our results, the sensitization rate to quaternium-15 was $12 \%$ for the whole population, but positive skin patch test reactions were observed only in the group of dental students. We could consider the importance of the exposure to disinfectants during the course of their practical education for the onset of the sensitization.
Imidazolidinyl urea is the second most common preservative used in cosmetic products (lotions, creams, hair conditioners, shampoos, deodorants) and topical drugs and affected $2.9 \%$ of patch test patients in 2005-2006 (20). It releases $1 / 8$ of the amount of formaldehyde that quaternium- 15 releases and is considered to be safer for patients with formaldehyde sensitivity (13). Cheng et al. (2014) evaluated patch test data at the National Skin Centre, Singapore, from 2006 to 2011. Sensitization frequencies among 3177 patients tested to preservatives in the standard series were all greater than $1 \%$ for, among other allergens, quaternium 15 (1.43\%), and less than $1 \%$ for imidazolidinyl urea. A rate of $0 \%$ was seen for formaldehyde (3). The results from our study indicate the importance of imidazolidinyl urea as a sensitizer in exposure during the educational process in dentistry - positive skin patch test reactions were established again only in the group of dental students.

Diazolidinyl urea affected $3.7 \%$ of patch test patients in 2005-2006 (20). Main sources are cosmetics (hair care products, body lotions, barrier creams and liquid soaps), topical medications, cleaning agents and detergents (21). Diazolidinyl urea is considered to be a stronger sensitizer than imidazolidinyl urea $(13,22)$. The latter statement was confirmed by the results from 
our pilot study. Sensitized to diazolidinyl urea were $30 \%$ from the group of dental students and $50 \%$ from the individuals from the group of dental patients. For comparison, no positive skin patch test reactions to imidazolidinyl urea among dental patients were established. Furthermore, the rate of sensitization to diazolidinyl urea in the whole studied by us population was the highest (34\%) if compared to the other studied preservatives, and was established to be significantly higher if compared to the ones for imidazolidinyl urea and for quaternium-15 for the whole studied population.

Concomitant contact allergy to formaldehyde and formaldehyde-releaser remains common. Furthermore, contact allergy to a formaldehyde-releaser was nearly always concomitant with another formaldehyde-releaser (23). A high degree of cross-reaction of diazolidinyl urea to formaldehyde and a lower cross-reaction associated with imidazolidinyl urea were reported (21). A common cross-reaction involves formaldehyde and quaternium-15; diazolidinyl urea cross-reacts with imidazolidinyl urea (2). Larotte et al. (2011) describe a subgroup of 25 patients who were sensitized to both imidazolidinyl urea and diazolidinyl urea, and only $24 \%$ of these were also sensitized to formaldehyde (18). According to Warshaw (2015), compared with the previous decade, positivity rates for all formaldehyde-releasing preservatives significantly decreased (formaldehyde - 6.6\%; quaternium 15 - 6.4\%; diazolidinyl urea - 2.1\%; imidazolidinyl urea 1.6\%) (24). Results from the present pilot study confirm our previous observation for high sensitization rates to formaldehyde in both dental students and dental patients (25). Our data confirm the observations of Maier et al. (2009) about a high degree of cross-reaction of diazolidinyl urea to formaldehyde, but the statistical analysis revealed a significantly higher rate of concomitant sensitization to diazolidinyl urea and to glutaraldehyde. No similar data were found in the available literature.

Glutaraldehyde is used as a disinfectant, as a tanning agent in leather, liquid fabric softener, as embalming fluid, in electron microscopy, as pharmacological agent used for hyperhidrosis and antifungal purposes. Owing to the known toxicities and sensitizing properties of glutaraldehyde, less offensive and presumably safer alternatives, such as ortho-phthalaldehyde, have been introduced (1). Health care workers were more likely to have work-related allergic contact dermatitis, especially, among other to glutaraldehyde (26). Warshaw et al. (2015) documented the North American Contact Dermatitis Group (NACDG) patch-testing results from 2011, to 2012. According to them, as com- pared with previous reporting periods positive reaction rates statistically increased for glutaral $(1.5 \%)$ and paraben mix (1.4\%) (24). The results obtained in our pilot study categorically confirm the later findings - the sensitization rates for glutaraldehyde were the highest observed in the group of dental students $(32.2 \%)$, and more than threefold higher if compared with the one in the group of dental patients (10\%). Furthermore, significantly higher rate of concomitant sensitization to formaldehyde and glutaraldehyde was revealed, being $66.7 \%$ for the group of dental students. Our findings categorically confirm the role of exposure to glutaraldehyde in dental practice for the onset of sensitization.

\section{CONCLUSION}

We consider the importance of exposure to diazolidinyl urea, quaternium-15, imidazolidinyl urea and glutaraldehyde during the course of practical education in dentistry for the onset of sensitization. The sensitization rates for glutaraldehyde were the highest observed in the group of dental students. The exposure to formaldehyde is ubiquitous and is difficult to distinguish the roles of environmental and occupational exposures. High rate of concomitant sensitization to diazolidinyl urea and to glutaraldehyde was revealed. Previously reported observations about high rate of concomitant sensitization to formaldehyde and glutaraldehyde were confirmed. The promotion of proper personal protection as well as adequate information on occupational chemical hazards should start as early as during the first years of education in dentistry.

Acknowledgement. The study was granted by the Medical University, Sofia - Project No. 4-C/2014 "Pilot investigation of urinary bisphenol $\mathrm{A}$ in students of dental medicine, students from Dental Technician School and in dental professionals, exposed during the practical education."

\section{Conflict of interests}

The authors declare there is no conflict of interests.

\section{Abbreviations}

NACDG - North American Contact Dermatitis Group

FRP - Formaldehyde-releasing preservatives

ICDRG - International Contact Dermatitis Research Group 


\title{
Sažetak
}

\section{PILOT STUDIJA KONTAKTNE SENZITIVNOSTI NA FORMALDEHID-POJAČIVAČE, FORMALDEHID I GLUTARALDEHID KOD STUDENATA STOMATOLOGIJE}

\author{
Lyapina Maya, ${ }^{1}$ Dencheva Maria, ${ }^{2}$ Krasteva Assya, ${ }^{2}$ Tzekova Mariana, ${ }^{2}$ \\ ${\text { Deliverska Mariela, }{ }^{3} \text { Kisselova Angelina }}^{2}$ \\ ${ }^{1}$ Department "Hygiene, Medical Ecology and Nutrition", Medical University - Sofia, Medical Faculty, Sofia, Bulgaria \\ 2 Department "Oral and Image Diagnostic", Medical University - Sofia, Faculty of Dental Medicine, Sofia, Bulgaria \\ 3 Department "Medical Ethics and Law", Medical University - Sofia, Faculty of Public Health, Sofia, Bulgaria
}

Uvod: Profesionalna kontaktna alergijska senzibilizacija je česta kod stomatološkog osoblja. Najčešći alergeni u stomatološkoj praksi su formaldehid-pojačivači, formaldehid i glutaraldehid.

Cilj: Cilj ovog rada bio je da se odredi stepen kontaktne senzibilizacije na formaldehid, kvaternium-15, imidazolidinil ureu, diazolidinil ureu i na glutaraldehid kod studenata stomatologije i stomatoloških pacijenata.

Materijal i metode: Ukupno 50 učesnika je uključeno u studiju: 40 studenata stomatologije je bilo izloženo formaldehid-pojačivačima, formaldehidu i glutaraldehidu tokom svoje nastave; 10 stomatoloških pacijenata bez profesionalnog izlaganja supstancama je služilo kao kontrolna grupa. Svi navedeni učesnici studije su bili izloženi patch testu na navedene alergene.

Rezultati: Nivo senzibilizacije na formaldehid je bio značajno viši u grupi stomatoloških pacijenata, u poređenju sa grupom studenata $\left(\chi^{2}=5.37 ; p=0.021\right)$. Pozitivni kožni patch testovi na kvaternijum-15 i na imidazolidinil ureu su uočeni samo u grupi studenata stomatologije. Uočen je značajno viši nivo senzibilizacije na di-

\section{REFERENCES}

1. Anderson SE, Meade BJ. Potential health effects associated with dermal exposure to occupational chemicals. Environ Health Insights. 2014; 17;8 (Suppl 1): 51-62.

2. Sasseville D. Hypersensitivity to preservatives. Dermatol Ther. 2004; 17(3): 251-63.

3. Cheng S, Leow YH, Goh CL, Goon A. Contact sensitivity to preservatives in Singapore: frequency of sensitization to 11 common preservatives 2006-2011. Dermatitis. 2014; 25(2): $77-82$.

4. Herbert C, Rietschel R. Formaldehyde and formaldehyde releasers: How much avoidance of cross-reacting agents is required? Contact Dermatitis. 2004; 50(6): 371-3.

5. Wetter DA, Yiannias JA, Prakash AV, Davis MD, Farmer SA, el-Azhary RA. Results of patch testing to personal care product allergens in a standard series and a supplemental cosmetic series: an analysis of 945 patients from the Mayo Clinic Contact Dermatitis Group, 2000-2007. J Am Acad Dermatol. 2010; 63(5): 789-98. azolidinyl ureu, u poređenju sa rezultatima dobijenim na imidazolidinyl ureu $\left(\chi^{2}=5.4 ; \mathrm{p}=0.02\right)$ i na kvaternijum-15 $\left(\chi^{2}=6.76 ; p=0.009\right)$, kao i na glutaraldehid, ako se poredi sa rezultatima dobijenim na kvaternijum-15 $\left(\chi^{2}=3.96 ; p=0.04\right)$ za celu ispitivanu populaciju. Za celu ispitivanu populaciju, zapažen je značajno viši nivo prateće senzibilizacije na formaldehid i glutaraldehid $\left(\chi^{2}=6.18 \mathrm{p}=0.013\right)$, kao i na diazolidinil ureu i na glutaraldehid $\left(\chi^{2}=9.12 \mathrm{p}=0.003\right)$.

Zaključak: Razmatrali smo značaj izloženosti i razvoj senzibilizacije na diazolidinyl ureu, kvaternijum-15, imidazolidinyl ureu i glutaraldehid tokom praktične nastave stomatologije. Izloženost formaldehidu je ubikvitarna i veoma je teško razlikovati posledice koje formaldehid ima u životnoj sredini i u profesionalnoj izloženosti. Unapređenje zaštite osoblja kao i adekvatna informisanost o opasnostima, koje prete od izloženosti ovim supstancama, treba da se započne što pre, po mogućstvu u prvoj godini studija stomatologije.

Ključne reči: kontaktna senzibilizacija, studenti stomatologije, formaldehid, zaštita od formaldehid-pojačivača, glutaraldehid.

6. Warshaw EM, Buchholz HJ, Belsito DV et al. Allergic patch test reactions associated with cosmetics: retrospective analysis of cross-sectional data from the North American Contact Dermatitis Group, 2001-2004. J Am Acad Dermatol. 2009; 60(1): 23-38.

7. Warshaw EM, Belsito DV, Taylor JS et al. North American Contact Dermatitis Group patch test results: 2009 to 2010. Dermatitis. 2013; 24(2): 50-9.

8. Bonnevie P. Aetiologie und Pthogenese der Ekzemkrankheiten. Kinische Studien uber die Ursachen der Ekzeme unter besonderer Berucksichtigung des Diagnostischen Wertes der Ekzemproben. Copenhagen, Denmark, Busch, 1939.

9. Jacob SE, Maldonado EA, Herro EM. Formaldehyde and formaldehyde releasing preservatives revisited. The Dermatologist. 2011; 19(6): 24-7.

10. The US Consumer Product Safety Commission (CPSC). An update on formaldehyde. 2013. Available at: http://www. cpsc.gov/PageFiles/121919/AN\%20UPDATE\%20ON\%20FR MALDEHYDE\%20final\%200113.pdf. Accessed October 21, 2015. 
11. Pontén A, Bruze M. Formaldehyde. Dermatitis. 2015; 26(1): 3-6.

12. Jacob SE, Steele T, Rodriguez G. Focus on T.R.U.E. test allergens \#21, 13, and 18: formaldehyde and formaldehyde-releasing preservatives. Skin and Aging. 2005; 13(12): 22-7.

13. Rietschel RL, Fowler JF, Jr, eds. Fisher's Contact Dermatitis. 6th ed. Hamilton, ON: BC Decker Inc.; 2008: 268-9.

14. Hamilton T, de Gannes GC. Allergic contact dermatitis to preservatives and fragrances in cosmetics. Skin Therapy Lett. 2011; 16(4): 1-4.

15. Rastogi SC. Analytical control of preservative labelling on skin creams. Contact Dermatitis. 2000; 43(6): 339-43.

16. Lachapelle J.M. Preservatives. In: Rustemeyer T, Elsner P, John SM, Maibach HI, eds. Kanerva's Occupational Dermatology. Berlin: Springer, 2012: 385-95.

17. de Groot AC, White IR, Flyvholm MA, Lensen G, Coenraads PJ. Formaldehyde-releasers in cosmetics: relationship to formaldehyde contact allergy. Part 1. Characterization, frequency and relevance of sensitization, and frequency of use in cosmetics. Contact Dermatitis. 2010; 62(1): 2-17.

18. Latorre N, Borrego L, Fern ndez-Redondo V et al. Patch testing with formaldehyde and formaldehyde-releasers: multicentre study in Spain (2005-2009). Contact Dermatitis. 2011; 65(5): 286-92.

\section{Correspondence to/Autor za korespondenciju}

Maya Lyapina, MD

Department of Hygiene, Medical Ecology and Nutrition, Medical Faculty, Medical University, 15 Blvd "Acad. Ivan Evstr. Geshov",

1431 Sofia, Bulgaria

Phone: +359887161768;

E-mail: saly_grigory@abv.bg
19. Kadivar S, Belsito DV. Occupational dermatitis in health care workers evaluated for suspected allergic contact dermatitis. Dermatitis. 2015; 26(4): 177-83.

20. Zug K, Warshaw EM, Fowler JF Jr et al. Patch-test results of the North American Contact Dermatitis Group 2005-2006. Dermatitis. 2009; 20(3): 149-60.

21. Maier LE, Lampel HP, Bhutani T, Jacob SE. Hand dermatitis: a focus on allergic contact dermatitis to biocides. Dermatol Clin. 2009; 27(3): 251-64.

22. Frosch PJ, Menne T, Lepoitteven JP. Contact dermatitis. 4th ed. Berlin: Springer-Verlag, 2006.

23. Lundov MD, Johansen JD, Carlsen BC, Engkilde K, Menné T, Thyssen JP. Formaldehyde exposure and patterns of concomitant contact allergy to formaldehyde and formaldehyde-releasers. Contact Dermatitis. 2010; 63(1): 31-6.

24. Warshaw EM, Maibach HI, Taylor JS et al. North American contact dermatitis group patch test results: 2011-2012. Dermatitis. 2015; 26(1): 49-59.

25. Lyapina M, Dencheva M, Krasteva A, Tzekova M, Kisselova-Yaneva A. Concomitant contact allergy to formaldehyde and methacrylic monomers in students of dental medicine and dental patients. Int. J. Occup. Med. Environ. Health. 2014; 27(5): 797-807.

26. Suneja T, Belsito DV. Occupational dermatoses in health care workers evaluated for suspected allergic contact dermatitis. Contact Dermatitis. 2008; 58(5): 285-90. 